\title{
THE LEVEL OF CAPITAL AND THE VALUE OF EU BANKS UNDER BASEL III
}

\author{
Barbora Šútorová, Petr Teplý*
}

\begin{abstract}
:
The 2007-2009 global financial turmoil was exacerbated by a low level of financial market regulatory coordination. Historical experience has shown that despite implementing regulations, supervision and macroeconomic policies, the financial industry regularly experiences crises. Consequently, a similar impact might be expected from the Basel III new bank regulatory framework. The aim of this paper is two-fold; in the first part dedicated to theory we describe the Basel III regulatory standards and argue that this regulation is not sufficient and will not prevent financial markets from experiencing future crises. Moreover, we discuss implementation of new banking regulation in Europe: the Capital Requirements Directive IV and stricter capital requirements for European banks set by the European Banking Authority in 2011. In the second part, we focus on an empirical analysis of the impact of stricter capital requirements as defined in the Basel III framework on the market value of European banks. Our analysis employs the fixed effects methodology on the financial data collected from 172 banks listed on European stock exchanges during the 2005-2011 period. We conclude that the impact of the Basel III regulation on the value of bank shares will probably be perceived negatively by the market, which could be reflected in a drop in the market value of the observed banks.
\end{abstract}

Keywords: bank, Basel III, capital, fixed effects methodology, market value, regulation.

JEL Classification: G18, G21, G32

\section{Introduction}

Poor design and a low level of international coordination of financial market regulations contributed significantly to the 2007-2009 global financial turmoil. In addition, the pending Eurozone crisis has highlighted the role of bank regulation and its impact on

* Barbora Š́torová, Institute of Economic Studies, Faculty of Social Sciences, Charles University in Prague (IES FSS UK), Opletalova 26, 11000 Prague 1 (barbora.sutorova@gmail.com);

Petr Teplý, IES FSS UK \& Faculty of Finance and Accounting, University of Economics, Prague, nám. W. Churchilla 4, 13067 Prague 3 (petr.teply@vse.cz).

This research was supported by the Czech Science Foundation (project GACR No. 14-02108S -

The nexus between sovereign and bank crises) and a project VŠE IP100040. 
economies. Reinhart and Rogoff (2009) argue that regulation, surveillance and sound macroeconomic policy do not suffice to prevent crises based on historical experience. A similar impact might be expected from the new regulatory framework on bank capital requirements defined by Basel III accords proposed by the Basel Committee on Bank Supervision (BCBS).

The aim of this paper is two-fold. First, in the theoretical part we discuss current, new banking regulations in Europe. Second, in the empirical part we analyse the possible impact of stricter capital requirements defined in the Basel III framework on the market value of European banks. To our best knowledge, there are no other studies that quantitatively analyse the potential impact of Basel III on the market value of banks. The paper continues as follows: in Section 2 we describe Basel III regulatory standards and argue that this regulation is not sufficient and will not prevent financial markets from experiencing future crises. Moreover, we discuss the current regulatory framework in Europe, the Capital Requirements Directive IV (CRD IV) and stricter capital requirements for European banks set by the European Banking Authority (EBA) in 2011. Section 3 presents the model and a related literature review. In Section 4, we analyse how investors investing into listed European banks would react to the stricter capital requirements under Basel III and which drivers are decisive for their judgments that, in turn, influence the market value of listed banks. Put it differently, we will test a hypothesis measuring whether the market would perceive higher capital requirements, lower risk taking and expected less risky balance sheets of banks under the Basel III proposal positively. For this purpose, we will conduct a panel data analysis for 172 European banks listed on European stock exchanges during the 2005-2011 period and employ the fixed effects methodology. Section 5 summarizes the conclusions and states final remarks.

\section{Basel III and Banking Regulation in the European Union}

This section consists of three main parts. The first part provides a theoretical background of financial market regulation. The second part deals with the Basel III regulation with a primary focus on stricter capital requirements. Finally, in the last part we discuss implementation of the new banking regulation in Europe.

\subsection{Theoretical background of financial market regulation}

There is currently pending a fierce debate about financial market regulation - its classical works include Stigler (1971), Dewatripont and Tirole (1994), Goodhart et al. (1998), Dvořák (2005) or more recently Acharya et al. (2010), Mandel and Tomšík (2011), Musílek (2011) or Revenda et al. (2012). On the one hand, there are logical points of view that higher capital requirements lead to (i) the healthier financial system through decreased risk of potential bank bankruptcies, (ii) lower systemic risk, and (iii) lower social costs as a result of the elimination of moral hazard, while these positives 
will substantially trade off any (if any) negative impacts of stricter capital rules. On the other hand, the counter arguments emphasize that higher capital requirements increase the costs of financing for banks (equity financing is relatively more expensive than debt financing), which would lead to (i) the slowdown of the loan growth and potential detrimental effects on the economies, and (ii) the decrease in profitability disabling future building of capital via retained earnings and eliminating future expansion of bank operations (Cosimano and Hakura, 2011). ${ }^{1}$

In this context, theories dealing with the efficiency of financial market regulation should be reviewed. For instance, Acharya et al. (2010) presents a few fundamental questions regarding this topic. First, we know that excessive regulation involves costs, but what are they? Second, we also know that in the presence of regulation, an unleashed disaster can be observed ex-post only. It implies that optimal regulation should be the art of balancing the immeasurable against the unknowable. As a result, effective financial market regulation is basically a "mission impossible" and recurring crises can be still expected in the future. Šinka and Teplý (2011) developed a regulation theory called "MAC questions in regulation". This theory raises three fundamental questions for regulators when regulating any industry or entity: i) Materiality (key questions: Are activities of a newly regulated entity material and significant? Does this future regulated entity play a significant role on the relevant market?); ii) Accountability (key questions: Is the regulated entity accountable, can the regulator identify it and perform effective regulation and supervision?); and finally iii) Credibility (key questions: How successful were similar regulations? Does any applicable best-practice regulation exist?). Effective regulation and supervision (i.e. expected benefits outweigh related costs) requires positive answers to all three questions. Šinka and Teplý (2011) demonstrate that both hedge fund and private equity regulation fail to give a positive answer to any of the questions and that these regulations are ineffective, which corresponds with reality.

Alternatively, Teplý et al. (2012) present a theoretical concept "5Gs of Effective Regulation" and discusses 5 guarantees (Gs) for achieving global effective regulation²: i) guarantee of strong supervisor (powerful and independent), ii) guarantee of international coordination (the supervisor should act globally), iii) guarantee of risk coverage (simple and easy capital ratios and risk management indicators of credit, market, liquidity, operational and systemic risks, stress tests, shocks absorption buffers etc.), iv) guarantee of bank crisis management (adequate bankruptcy law, crisis resolution, deposit insurance, recapitalization rules etc.), and finally v) guarantee of personal responsibility (regulators should have personal responsibility and adequate remuneration, which does not hold in practice, however). Teplý et al. (2012) conclude that the $5 \mathrm{Gs}$ are not simultaneously achievable, so there is a challenge to implementing

1 For a detailed theoretical discussion about arguments supporting and criticizing Basel III rules and an empirical verification of some of them, see Š́torová (2012) or Klinger and Teplý (2014).

2 Effective regulation in this context means that benefits of regulatory rules outweigh the related costs. i.e. the similar definition applied in Šinka and Teplý (2011). 
effective regulation. As a result, global regulatory efforts will not prevent financial markets from future crises and financial upheavals, which correspond to the findings of Reinhart and Rogoff (2009) or Reihart and Rogoff (2009) or Acharya et al. (2010).

\subsection{Basel III background}

The overall objective of Basel III is to strengthen global capital, liquidity and risk assessment rules to ensure a higher level of resiliency in the banking sector. The reason for changing and complementing preceding rules $\left(\right.$ Basel $\left.\mathrm{II}^{3}\right)$ was to prevent the consequences of market failures revealed by the crisis by improving the banking sector's ability to absorb shocks arising from financial and economic stresses (BCBS, 2010). The main channels for accomplishing these goals include increasing the quantity and enhancing the quality of capital, enhancing risk coverage and introducing liquidity requirements. All of the measurements are supported by defining more tight and precise market discipline and supervision (BCBS, 2011b). Despite the fact that Basel III should mean an improvement compared to Basel II capital accords, we agree with Teplý et al. (2012) who state that the Basel III regulation is not sufficient and will not prevent financial markets from future crises due to its expected calibration, delayed implementation and strong pressure from bank lobbyists.

Since this paper focuses primarily on the higher capital requirements set by Basel III, we will discuss this topic in more detail. As described in BCBS (2010), Basel III distinguishes two main types of capital: Tier 1 and Tier 2 which together form Total regulatory capital. Tier 1 (going-concern capital) further consists of: i) Common equity ratio that includes mainly issued commons shares, retained earnings and additional Tier 1 capital which includes instruments that are "subordinated, have fully discretionary non-cumulative dividends or coupons and have neither a maturity date nor an incentive to redeem" (BCBS, 2010, p.2); and ii) Additional Tier 1 capital that encompasses further elements of bank capital as defined by BCBS (2011b). Tier 2 capital (gone-concern capital) includes chiefly subordinated debt and certain loan loss provisions. First, in order to achieve a high quality capital base the following capital ratios were introduced in Basel III or their values were raised compared to Basel II:

i) Minimum common equity (as a percentage of risk-weighted assets, "RWA") - an increase from $2 \%$ to $4.5 \%$.

ii) Minimum Tier 1 capital as a percentage of RWA - an increase from $4 \%$ to $6 \%$.

iii) Minimum total capital (including both Tier 1 and Tier 2 capital) as a percentage of RWA - the same level of $8 \%$.

3 For more details on Basel II and related risk management practices, see, for instance, Teplý et al. (2007), Lall (2010), Matejašák et al. (2009), or more recently Rippel and Teplý (2011), Černohorská et al. (2012), Rippel et al. (2012), Teplý (2012) or Stádník (2013, 2014). We also should mention the so called Basel 2.5 published by BCBS (2009) that set new regulatory standards for trading book of a bank. 
Second, a capital conservation buffer rule has been introduced to reflect the procyclical behaviour of banks beginning in 2016. During fairly stable times, a capital conservation buffer up to $2.5 \%$ of common equity must be held on top of the minimum capital requirements. In times of financial stress, banks can use the buffer unless they make earnings distributions such as bonuses and dividends (BCBS, 2011a).

Third, BCBS (2011b) imposes for Systemically Important Financial Institutions $\left(\mathrm{SIFIs}^{4}\right)$ additional loss absorbency requirements ranging from $1 \%$ to $2.5 \%$ of common equity depending on a bank's systemic importance. This should discourage banks from becoming even more systemically important and lower negative externalities of SIFIs. The higher loss absorbency requirements will be introduced in parallel with the Basel III capital conservation and countercyclical buffers, i.e. between 1 January 2016 and year end 2018, becoming fully effective on 1 January 2019. Figure 1 summarizes the structure of bank capital after full implementation of Basel III for both normal banks and SIFIs.

Figure 1: The Structure of Bank Capital after Full Implementation of Basel III

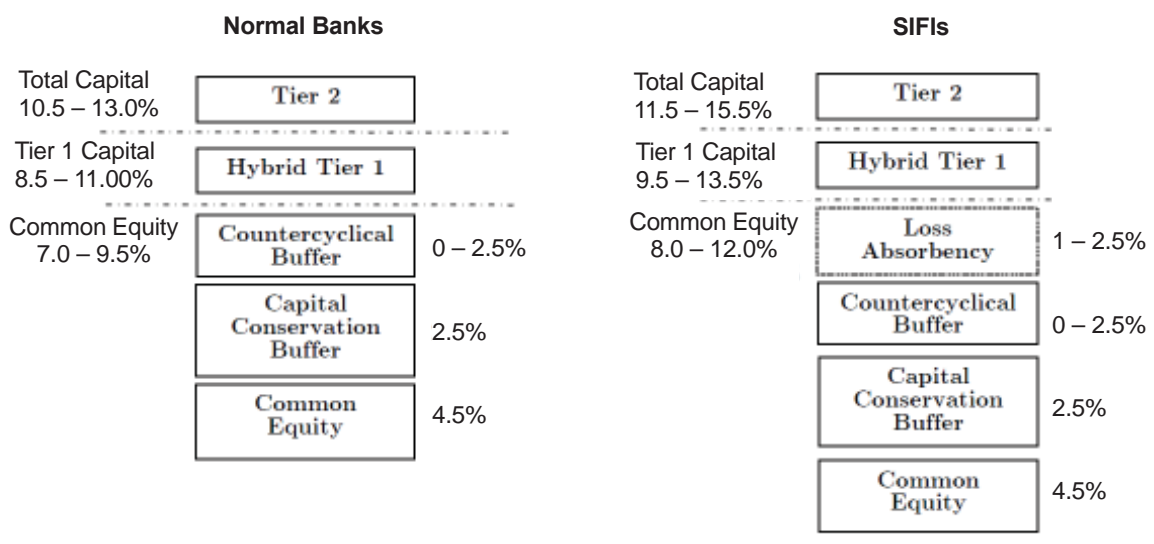

Source: Authors based on BCBS (2010) and BCBS (2011b).

Not surprisingly, regulatory efforts on higher capital requirements will affect bank performance negatively. For example, it is estimated that the current regulatory efforts will decrease overall global bank profitability measured by return on average equity (ROAE) from $15-20 \%$ in the $2004-2007$ pre-crisis period to estimated $10-12 \%$ after the year 2013 (Oliver Wyman and Morgan Stanley, 2012; PWC, 2012). McKinsey

4 We should note that a SIFI is a national specific subject to local regulator's discretion. For instance, the Swiss regulator currently requires SIFIs to hold a capital conservation buffer of $8 \%$ and a $6 \%$ progressive systemic surcharge resulting in total capital ratio of $19 \%$ RWA. However, in November 2011 the BCBS and the Financial Stability Board identified 29 Global-Systemically Important Financial Institutions (G-SIFIs) that will be supposed to hold an extra capital surcharge ranging from $1.0 \%$ to $2.5 \%$. 
(2012) estimates that Basel III rules will diminish ROAE in banking sectors in France, Germany and the UK by 2.9, 2.8 and 2.1 percentage points in the future, respectively.

There are numerous views regarding the impact of the proposed capital requirements on bank deleveraging and the subsequent consequences on economies. In theory, one can distinguish three main ways of bank deleveraging: capital increase, reducing (risk-weighted) assets and restricting lending (Wehinger, 2012). First, capital increase is sometimes called 'good deleveraging' since it occurs on banks' liabilities via building capital and therefore comes at the costs of shareholders. However, due to a bleak economic outlook in the Eurozone and improper valuation of many 'zombie banks' ${ }^{5}$, neither new nor current shareholders of these banks are willing to provide additional funding. Second, bankers might reduce required capital requirements through decreasing risk-weighted assets via sales of assets or their 'reshuffling', which seems problematic under the current unfavourable conditions in the Eurozone. Finally, deleveraging might occur through restricting lending of banks sometimes called 'bad deleveraging' because of its negative impact on the economic output via either higher interest rates charged by banks or via asset contraction resulted in credit crunch. As a result of the deleveraging and other regulatory efforts, we expect a rise in shadow banking activities in the Eurozone in the near future.

\subsection{Implementation of new banking regulation in Europe}

The implementation of the new banking regulations will have some specific characteristics in Europe. First, the European Union (EU) will implement Basel III rules according to the Capital Requirements Directive IV (CRD IV) published by European Commission in July 2011. Second, the EU needs to make capital requirements for its banks even stricter as a consequence of the sovereign debt crisis spreading across the Eurozone. Both regulations are analysed below in more detail.

5 See Onaran (2011) for more details. We define a zombie bank as a financial institution with i) a price-to-book value ratio smaller than 1 , ii) a negative economic worth, iii) mispriced assets and iv) support by government' bail-outs and guarantees. Zombie banks include, for example, Allied Irish Banks, Bank of AMerica, Crédit Immobilier de France, German Landesbanken, Spanish Cajas or Royal Bank of Scotland that should have bankrupted rather than have been rescued for political reasons. Many zombie banks are still present in Japan, what gives a negative example to follow as these banks do not provide lending to the economy and therefore do not fulfil their basic function. We expect that a similar situation will occur in the Eurozone and that the zombie banks will hamper economic recovery in coming years. 
Table 1

Overview of Capital Requirements Directive IV

\begin{tabular}{|c|c|c|c|}
\hline \multicolumn{2}{|c|}{$\begin{array}{c}\text { Directive } \\
\text { (Strong links with national laws, } \\
\text { less prescriptive) }\end{array}$} & \multicolumn{2}{|c|}{$\begin{array}{c}\text { Regulation } \\
\text { (Detailed and highly prescriptive provisions } \\
\text { establishing a "single rule book") }\end{array}$} \\
\hline $\begin{array}{l}\text { Corporate } \\
\text { governance }\end{array}$ & $\begin{array}{l}\text { - increasing the effectiveness of } \\
\text { risk oversight by boards } \\
\text { - improving the status of the risk } \\
\text { management function } \\
\text { - ensuring effective monitoring } \\
\text { by supervisors of risk } \\
\text { governance }\end{array}$ & Capital & $\begin{array}{l}\text { total capital requirement is } \\
8 \% \text { (common equity } 4.5 \% \text { ) } \\
\text { plus two supplementary } \\
\text { layers, which each can } \\
\text { amount to } 2.5 \% \text {, or even } \\
\text { more for the counter-cyclical } \\
\text { buffer }\end{array}$ \\
\hline Supervision & $\begin{array}{l}\text { - preparation of an annual super- } \\
\text { visory program for each firm } \\
\text { - greater use of on-site } \\
\text { supervisory assessments } \\
\text { - more intrusive and forward- } \\
\text { looking supervisory } \\
\text { assessments }\end{array}$ & Liquidity & $\begin{array}{l}\text { introducing a Liquidity } \\
\text { Coverage Ratio - the exact } \\
\text { composition and calibration } \\
\text { will be determined after } \\
\text { an observation and review } \\
\text { period in } 2015\end{array}$ \\
\hline Sanctions & $\begin{array}{l}\text { appropriate administrative } \\
\text { sanctions and measures } \\
\text { with respect to violations of } \\
\text { EU banking legislation (e.g. } \\
\text { administrative fines of up to } 10 \% \\
\text { of an institution's annual turnover) }\end{array}$ & $\begin{array}{l}\text { Leverage ratio } \\
\text { requirement } \\
\text { (January 2018) }\end{array}$ & $\begin{array}{l}\text { introducing a leverage ratio } \\
\text { will be subject to supervisory } \\
\text { review, and the implications } \\
\text { will be closely monitored } \\
\text { prior to its possible move } \\
\text { to a binding requirement in } \\
\text { January } 2018\end{array}$ \\
\hline \multirow[b]{2}{*}{$\begin{array}{l}\text { Reliance } \\
\text { on external } \\
\text { ratings }\end{array}$} & \multirow{2}{*}{$\begin{array}{l}\text { - reducing the reliance by credit } \\
\text { institutions on external credit } \\
\text { ratings by requiring institutions } \\
\text { to: } \\
\text { - base their investment } \\
\text { decisions on their own internal } \\
\text { credit opinion } \\
\text { - develop internal ratings } \\
\text { for portfolios in which they } \\
\text { have a material number of } \\
\text { exposures }\end{array}$} & $\begin{array}{l}\text { Counterparty } \\
\text { credit risk }\end{array}$ & $\begin{array}{l}\text { consistent with the EC's } \\
\text { policy vis-à-vis over } \\
\text { the counter derivatives, } \\
\text { changes are made to } \\
\text { encourage banks to clear } \\
\text { OTC derivatives on central } \\
\text { counterparties }\end{array}$ \\
\hline & & $\begin{array}{l}\text { Capital } \\
\text { buffers }\end{array}$ & $\begin{array}{l}\text { introducing two capital } \\
\text { buffers on the top of } \\
\text { the minimum capital } \\
\text { requirements: a capital } \\
\text { conservation buffer identical } \\
\text { for all EU banks, and } \\
\text { a countercyclical capital } \\
\text { buffer to be determined at } \\
\text { national level }\end{array}$ \\
\hline
\end{tabular}

Source: Authors based on European Commission (2011) and PwC (2011).

\subsubsection{Capital Requirements Directive IV}

CRD IV implements Basel III for more than 8,300 banks that operate in the EU (representing about $50 \%$ of the world's global banking assets). On the top of the rules required by Basel III, it introduces a number of additional changes to the banking 
regulatory framework. Moreover, while Basel III rules apply only to "internationally active banks", CRD IV ensures their application to all banks as well as investment firms in the EU. CRD IV is composed of two parts: (i) Directive that contains additional rules complementing Basel III about deposit-taking activities; and (ii) Regulation that provides detailed prudential requirements for financial institutions. The specific of CRD IV is an introduction of a "single rule book" that should help to avoid the danger of divergent national rules, secure harmonization in financial regulation across nations and contribute to a more effective functioning of the Single Market (European Commission, 2011). Table 1 summarizes key features of CRD IV from several points of view.

\subsubsection{Stricter capital requirements for European banks}

As a reaction to the potential negative outcomes of the sovereign debt crisis, in December 2011 the EBA published a formal "Recommendation" related to European banks' recapitalization needs. This Recommendation is a part of a broader European package agreed by the European Council and ECOFIN Council that is supposed to address the current situation in the EU (the whole EU not only Eurozone) by restoring stability and confidence in banks and financial markets. The new European agreed rules are stricter than global Basel III rules.

The EBA (2011a) rules require that banks to establish and keep an exceptional and temporary buffer such that the Core Tier 1 capital reaches a level of $9 \%$ by the end of June 2012 (in comparison with Tier 1 capital ratio of $6 \%$ under Basel III). During stress testing, the EBA identified a EUR 115 billion shortfall of a Tier 1 capital for 37 European banks. Nevertheless, these estimates seem rather underestimated as opposed by Open Europe (2011) that estimated a capital shortfall of EUR 260-372 billion for European banks, which is closer to reality taking into consideration the pending problems of banks on the Eurozone's periphery, such as Greece or Spain. We agree with Eichengreen (2014) stating that the European Banking Union (EBU) is deeply flawed. ${ }^{6}$ We assume that results of the Asset Quality Review (AQR) to be undertaken by the ECB will be biased and its outcome will be negative either for some EU governments or for the ECB. If the AQR is done properly, zombie banks will be revealed but not all EU governments will have enough money for their bailouts. If not done properly, zombie banks will fail later and the ECB will lose its reputation. We consider the EBU as the Trojan Horse of EU integration rather an effective tool for rescuing both EU banks and the Eurozone in the long-term.

Despite the fact that different banks will react differently to the above-mentioned capital shortfalls, the following mix of strategies might be expected: retention of future earnings, equity issuance, and reducing RWAs. Fitch (2012) estimates that an average bank out of analysed 29 G-SIFIs could meet its estimated shortfall of USD 19.5 billion to satisfy the $10 \%$ Basel III capital ratio through one year of retained earnings (USD 6 billion), new equity issuance (USD 6 billion) and finally through RWA reduction resulted in

6 See European Commission (2014) for more details on the EBU and the AQR. 
USD 7.5 billion capital surplus. When considering problems of the Eurozone banks, capital increase via retained earnings and additional equity issuance will be limited. As a consequence, the Eurozone banks are supposed to react to higher CRD IV capital requirements primarily through asset contraction (credit crunch). We believe that this deleveraging together with further regulatory rules under Basel III and the existence of zombie banks will hinder rather than spur economic recovery in the Eurozone in the short-term. To support our argumentation, we mention IMF (2012) that estimated an approximately 2\% negative impact on the Eurozone GDP by the end of 2013 (in the worst case scenario of poorly managed deleveraging bone by the banks).

\section{Theoretical Background of the Model}

In this section we present a theoretical background to our empirical analysis. The goal of the empirical analysis is to provide an answer to the question "What is the potential impact of strengthened capital requirements on banks' value in the EU?" Even though this question is relevant and interesting, it is not so frequently acknowledged in the connection with discussing the potential effects of the capital regulations. Whether the impact of increased capital levels will be positive or negative, both scenarios are justifiable. If the bank's value decreases as a result of holding more capital, this is because the market reacts negatively to a decreased level of bank's profitability. In case of a positive reaction reflected into a higher market value, investors appreciate decreased bank risk (as the aim of Basel III is to make banks "more healthy and safe" we will test the hypothesis whether higher capital requirements will be a positive signal for the equity markets). Further in this section, we first present a literature review of key works dealing with banks' value-capital relationship; and second, we present construction of the model based on standard methodologies applied in panel data analysis: the fixed effects and random effects methodologies.

\subsection{Literature review}

There exist three different points of view (leading to different results) about the relationship between the level of held capital and a bank's value. First, there is a generally known theorem of Modigliani and Miller developed as early as in 1958 stating that "the market value of any firm is independent of its capital structure and is given by capitalizing its expected return at the rate appropriate to its class" (Modigliani and Miller, 1958, p. 268). Even though some authors claim that the principle of financial intermediation creates informational and other types of frictions, so this principle does not apply to banks, as Miller (1995) expressed his insistence on his original indifference theorem.

Second, the academics in the 1970s pioneered the finding that if the capital ratio is increased via issuing new equity, the relationship between the capital level and the market value of a bank is negative (Ross, 1977; Myers and Majluf, 1984). The rationale behind this is built on four pillars: (i) a downward sloping demand curve for a given 
company shares, (ii) a negative perception of issuing equity by rational investors ${ }^{7}$, (iii) loosing part of advantageous tax effects and debt-related transparency of information effects, and (iv) large transaction costs associated with equity issuance with potential negative effect on company's operation. Typical representatives of literature dealing empirically with this issue are Masulis and Korwar (1985), who found a negative stock price change after secondary offerings for both industrials and services providing firms.

Third, there exists a channel of literature that directly quantifies the relation between the level of required capital and the bank's value (which we also analyse in this study), while the majority of studies belonging to this channel find a positive relation. Valkanov and Kleimeier (2007) investigated the role of regulatory capital in bank mergers and acquisitions (M\&A) in the USA and Europe and found that capital is perceived valuable by banks' buyers. They took the excess of regulatory capital as a key variable and identified that high excess-capital targets are valued more by the market than their less capitalized counterparts. The theoretical model verified by empirical data on bank M\&A presented by Mehran and Thakor (2009) showed that the cross-section of banks' value is increasing in capital, no matter how the value is measured. Specifically, they found that the total bank value and its components (purchase price, goodwill, and net present value to shareholders) are all increasing in the equity capital of the acquired bank. To the best of our knowledge, there is no other research or study taking a closer look at the immediate impact of the regulatory obligation for banks to increase their capital ratios on their value. Table 3 in Section 4 provides an overview of existing findings (including additional relevant studies to those discussed above) and compares it with our results.

\subsection{The model}

To estimate the effect of capital levels on European bank value, we use a panel data model in which the bank value is represented by its market capitalization. The suitability of market capitalization as a figure representing the bank value is obvious because this figure is generally accepted by the investment community to determine the bank's actual value. The equation used to model the relationship of the bank's market value and the level of capital is built on four key variables: value, capital, profitability and risk, while other variables are incorporated to control for other potential significant effects influencing the bank value:

$$
\begin{gathered}
\ln \Delta \text { VALUE }_{i, t}=\alpha_{0}+\alpha_{1}(K / A)_{i, t-1}+\alpha_{2} \text { PROF }_{i, t}+\alpha_{3} \text { RISK }_{i, t} \\
+\alpha_{4} \text { PB }_{i, t}+\alpha_{5} \text { PPS }_{i, t}+\alpha_{6} \text { LoanQual }_{i, t}+\alpha_{7} \text { INDEX }_{i, t} \\
+\alpha_{8} \ln \text { Assets }_{i, t}+\varepsilon_{i, t}
\end{gathered}
$$

7 Investors believe that the newly issued equity is accompanied by the effects of superior information of management compared to investors. Managers know the intrinsic value of company's stock and prefer seasonal offering when the intrinsic value is lower than the current market value. However, rational investors expect this and therefore sell their shares, what lowers the market price of the company's shares. 
where:

$\ln \triangle V A L U E_{i, t}$ Bank value is represented by a change in natural logarithm of market capitalization. Market capitalization is equal to the price per share multiplied by the number of shares outstanding. We include logarithmic change of the variable (in principle returns) as it better captures the reaction of investors to the level of capital

$(K / A)$ Lagged Common equity/Tier 1/Total capital ratio. The variable is lagged because market needs time to express the reaction to the level of held capital

PROF $_{i, t} \quad$ Profitability level represented by return on average assets (ROAA)

$R I S K_{i, t} \quad$ Risk measured by the ratio of risky assets to total assets in the bank's portfolio

$P B_{i, t} \quad$ Price to book ratio

$D P S_{i, t} \quad$ Dividends per share used to capture to what extent paid dividends are a motivation for investors to buy the shares of a given bank and thus improve its market performance

LoanQual $_{i, t}$ Quality of loans measured by the ratio of non-performing loans to gross loans. The variable is included to capture the health of the bank from the assets point of view

INDEX $X_{i, t} \quad$ Main index of the stock market where the bank is quoted. This variable captures the effect of overall situation on the stock market and substitutes other control variables of economic activity, such as GDP and inflation

$\ln$ Assets $_{i, t} \quad$ Natural logarithm of total assets used to control for the size effect

\section{Empirical Analysis}

In this empirical part we have applied two standard methodologies commonly used in panel data analysis: the fixed effect methodology (for more details see Laird and Ware (1982) or Fitzmaurice et al. (2004)) and random effects methodologies (for a detailed description we refer to works by Burnham et al. (2002) or Athanasoglou et al. (2006)). The data for modelling were obtained from the BankScope database and cover the period of 2005-2011. The banks were selected according to their specialization and due to the nature of the models applied, only banks with "standard activities", such as deposits taking and loans providing, were involved in the modelling. These banks include commercial banks, bank holding companies, saving banks, mortgage banks and cooperative banks. The database provided complete required data on 172 European banks listed on European stock exchanges in the 2005-2011 period. The panel data model represented by Equation (1) was estimated using the fixed effects methodology (FE) as it was diagnosed to be a more suitable model than the random 
effects for our data set measured by the Hausman specification test. ${ }^{8}$ It is important to note that we model the situation historically and base our conclusions about the potential future impact of Basel III capital adequacy rules on the assumption that the identified behaviour will have a persistent character. This means that we assume that reactions of banks, banks-related variables and investors will respond to similar stimuli in the same way in the future as they did in the past.

Table 2 reports results of the FE methodology including all three types of capital ratios. The results indicate that investors react negatively to higher levels of bank capital, which is reflected into a negative reaction of banks' market capitalization performance 9 . In order to analyse the principles on which the whole system "valuecapital-profitability-risk" was identified to work, the estimated coefficients and their interconnectedness should be examined in more detail. The direct negative relationship between the level of held capital and a change in market capitalization is valid with statistical significance for all three employed capital ratios. To put the results more specifically, an increase in common equity ratio, Tier 1 ratio and Total capital ratio by one percentage point in the past leads to a negative change in market capitalization of banks by $13.3 \%, 3.7 \%$ and $4.5 \%$, respectively. ${ }^{10}$ The positive relationship between bank profitability and the change in market capitalization reported by our model confirmed the market principle that investors are naturally willing to pay more for shares of better performing banks. This result corresponds to reality because current regulatory efforts will, as discussed above, decrease overall global banks' profitability measured by return on average equity (ROAE) from $15-20 \%$ in the $2004-2007$ pre-crisis period to estimated 10-14\% after the year of 2013 (McKinsey, 2012; Oliver Wyman and Morgan Stanley, 2012; PWC, 2012).

In addition, based on the values of estimated coefficients, the level of profitability is considered to be a more important factor influencing buying/selling decisions of investors than the level of risk. This is because of the following reasons: (i) the relation between risk and a change in the market value was identified to be positive (but insignificant), which means that investors do not tend to punish banks for undertaking more risky projects as they are expected to bring higher returns, (ii) the relationship between the quality of loans (proxied by non-performing loans) and the change in market capitalization showed to be positive, which adds to point (i) that investors are not afraid of buying shares of more risky banks.

8 Detailed results of appropriate tests are shown in Appendix.

9 As already mentioned above, we believe that including the performance of market capitalization is the best indicator for the studied relationship as it also captures the return to investors. However, during the modelling we checked also for a relationship between the absolute value of market capitalization and capital ratios and it showed to be negative, as well.

10 In the equation, the dependant variable is in natural logarithm, therefore, we interpret the coefficients in percentages (Wooldridge, 2009). 
Table 2

Results for Equation (1) Using the Fixed Effects Methodology

\begin{tabular}{|c|c|c|c|}
\hline \multicolumn{4}{|c|}{ Dependent Variable In $\triangle V^{\prime} A L U E_{i, t}$} \\
\hline & $\begin{array}{c}\text { Common } \\
\text { Equity Ratio }\end{array}$ & Tier 1 Ratio & $\begin{array}{c}\text { Total } \\
\text { Capital Ratio }\end{array}$ \\
\hline Const. & $\begin{array}{l}-9.791^{* *} \\
(3.855)\end{array}$ & $\begin{array}{c}-14.209^{* *} \\
(4.546)\end{array}$ & $\begin{array}{c}-14.990^{* \star *} \\
(3.708)\end{array}$ \\
\hline$(K / A)_{i, t-1}$ & $\begin{array}{c}-0.133^{* \star *} \\
(0.030)\end{array}$ & $\begin{array}{c}-0.037^{\star * *} \\
(0.012)\end{array}$ & $\begin{array}{c}-0.045^{\star *} \\
(0.020)\end{array}$ \\
\hline PROF $_{i, t}$ & $\begin{array}{c}0.184^{* * *} \\
(0.065)\end{array}$ & $\begin{array}{l}0.153^{* *} \\
(0.069)\end{array}$ & $\begin{array}{l}0.175^{\star *} \\
(0.068)\end{array}$ \\
\hline$R I S K_{i, t}$ & $\begin{array}{c}0.005 \\
(0.005)\end{array}$ & $\begin{array}{c}0.004 \\
(0.006)\end{array}$ & $\begin{array}{c}0.005 \\
(0.005)\end{array}$ \\
\hline$P B_{i, t}$ & $\begin{array}{l}0.335^{* * *} \\
(0.052)\end{array}$ & $\begin{array}{c}0.427^{* * *} \\
(0.062)\end{array}$ & $\begin{array}{l}0.376^{* * *} \\
(0.053)\end{array}$ \\
\hline$D P S_{i, t}$ & $\begin{array}{l}0.005^{\star *} \\
(0.002)\end{array}$ & $\begin{array}{l}0.004^{*} \\
(0.002)\end{array}$ & $\begin{array}{l}0.004^{*} \\
(0.002)\end{array}$ \\
\hline LoanQual $_{i, t}$ & $\begin{array}{l}0.210^{* * *} \\
(0.036)\end{array}$ & $\begin{array}{l}0.210^{* * *} \\
(0.037)\end{array}$ & $\begin{array}{l}0.232^{* * *} \\
(0.038)\end{array}$ \\
\hline$I_{\text {INDEX }}$ & $\begin{array}{l}0.005^{\star * *} \\
(0.001)\end{array}$ & $\begin{array}{l}0.005^{\star \star *} \\
(0.001)\end{array}$ & $\begin{array}{c}0.006^{* * *} \\
(0.001)\end{array}$ \\
\hline In Assets $_{i, t}$ & $\begin{array}{l}0.507^{* *} \\
(0.205)\end{array}$ & $\begin{array}{c}0.718^{* * *} \\
(0.245)\end{array}$ & $\begin{array}{c}0.771^{* * *} \\
(0.198)\end{array}$ \\
\hline$R^{2}$ & $55.66 \%$ & $53.80 \%$ & $52.78 \%$ \\
\hline
\end{tabular}

Note: Standard errors are in parentheses, ${ }^{* * * / * * / *}$ indicate $99 \% / 95 \% / 90 \%$ level of significance.

Source: Authors using data from the BankScope.

Turning attention to other included variables, all coefficient reporting significant results are in accordance with trading principles, i.e. dividend per share, price to book ratio and stock market index performance pull the change in market capitalization in a positive direction.

\subsection{Summary of results}

To summarize, investors do not appreciate higher capital ratios when deciding which shares to purchase in spite of the fact that the higher the level of capital, the lower the risk of banks. The level of profitability that is decreased by keeping more capital ${ }^{11}$ is a cardinal decision factor in our model and significantly positively influences the value of a bank. Therefore, both of these characteristics describing investors' decision taking lead to a negative relationship between the performance of banks' shares and a past

11 For an empirical analysis of capital-profitability relationship under Basel III for EU banks, see Šútorová and Teplý (2013). 
change in capital ratios, which, in principle, corresponds to the findings of Asquith and Mullins (1986) and Masulis and Korwar (1985), a detailed comparison with other authors is included in Table 3. Our results and discussion connote that we have to reject our tested hypothesis expecting a positive impact of higher capital requirements on the market value of banks, because investors are expected to appreciate mainly the lower risk taking and less risky balance sheets of banks.

Table 3

Overview of Key Empirical Works Dealing with Banks' Value-Capital Relationship

\begin{tabular}{|c|c|c|c|}
\hline Authors & Short description & Methodology and data used & $\begin{array}{l}\text { Capital } \\
\text {-value } \\
\text { relationship }\end{array}$ \\
\hline $\begin{array}{l}\text { Asquith } \\
\& \text { Mullins } \\
(1986)^{*}\end{array}$ & $\begin{array}{l}\text { Investigates the effect on } \\
\text { stock prices of seasoned } \\
\text { equity offerings }\end{array}$ & $\begin{array}{l}\text { Statistical analysis of excess } \\
\text { stock returns of } 531 \text { common } \\
\text { stock offerings between 1963-1981 }\end{array}$ & Negative \\
\hline $\begin{array}{l}\text { Masulis } \\
\& \text { Korwar } \\
(1985)^{*}\end{array}$ & $\begin{array}{l}\text { Examination of common } \\
\text { stock price adjustments } \\
\text { to announcements of } \\
\text { underwritten common } \\
\text { stock offerings }\end{array}$ & $\begin{array}{l}\text { Statistical analysis of data on } \\
\text { seasoned issues over the period } \\
\text { of } 1963-1980\end{array}$ & Negative \\
\hline $\begin{array}{l}\text { Valkanov } \\
\text { \& Kleimeier } \\
(2007)\end{array}$ & $\begin{array}{l}\text { Investigating the role of } \\
\text { regulatory capital in bank } \\
\text { M\&As }\end{array}$ & $\begin{array}{l}\text { Standard event study methodology } \\
\text { with focus on excess regulatory } \\
\text { capital using data on M\&As in } \\
1997-2003 \text { in the USA and Europe }\end{array}$ & Positive \\
\hline $\begin{array}{l}\text { Mehran } \\
\text { \& Thakor } \\
(2009)\end{array}$ & $\begin{array}{l}\text { Analyzing how bank } \\
\text { capital structure and value } \\
\text { (including components of } \\
\text { value) are correlated in the } \\
\text { cross section }\end{array}$ & $\begin{array}{l}\text { Dynamic theoretical model of } \\
\text { banks capital decisions verified } \\
\text { by regression analysis using data } \\
\text { on M\&As announced in the period } \\
\text { of } 1989-2007 \text { in the USA }\end{array}$ & Positive \\
\hline $\begin{array}{l}\text { Demirguc- } \\
\text { Kunt, } \\
\text { Detragiache, } \\
\& \text { Merrouche } \\
(2010)\end{array}$ & $\begin{array}{l}\text { Analyzing whether } \\
\text { better capitalized banks } \\
\text { experienced higher stock } \\
\text { returns during the financial } \\
\text { crisis }\end{array}$ & $\begin{array}{l}\text { Panel data regression on data for } \\
\text { banks in } 12 \text { economies during the } \\
\text { period Q1.2005-Q1.2009 }\end{array}$ & Positive \\
\hline This study & $\begin{array}{l}\text { Analyzing whether } \\
\text { better capitalized banks } \\
\text { experienced higher stock } \\
\text { returns during the financial } \\
\text { crisis }\end{array}$ & $\begin{array}{l}\text { Panel data regression on data for } \\
172 \text { banks in the EU during the } \\
\text { period of } 2005-2011\end{array}$ & Negative \\
\hline
\end{tabular}

*The literature on the decline of stock prices as a result of equity offering is extensive and dates back to 1980s, 1990s. Here, we provide just sample studies.

Source: Authors. 


\subsection{Further research opportunities}

Despite the conclusions mentioned above, there are still several ways in which our research can be improved. First, a similar study can be done on a larger sample of data including banks from a broader geographic area (we used the data from 172 banks in the EU). Second, the research focused on the impact of Basel III on the level of capital and the value of EU banks, while other consequences of Basel III might be researched, such as the impact on EU banks' lending rates, profitability and risk adjustment decisions). Finally, further quantitative and especially qualitative factors should be examined as we employed only bank specific variables in our analysis. Other variables, such as macroeconomic conditions, factors influencing individual investor behaviour or a bank's future strategic development, are also perceived by investors and can influence the value of banks. Additionally, the banking sector reacts dynamically to internal and external conditions so naturally, the new regulatory framework will affect the banking industry in other several ways. For example, McKinsey (2011) presents three key implications of the regulation for the European retail banking industry: i) repricing banking products, ii) business-model changes (including adjustment of the product and service mix, a review of the geographical and legal structure, and a possible exit from non-profitable business activities), and finally iii) need to develop strategic agenda of a bank in terms of its scale, regional footprint and risk.

\section{Conclusion}

This paper deals with both the theoretical and the practical aspects of the new banking regulations in the European Union. In the theoretical part, we discussed both positives and negatives of financial markets regulation and conclude that effective regulation (i.e. its benefits are higher than its costs) is a "mission impossible" as highlighted by Acharya et al. (2010). Moreover, we focus on the Basel III banking regulation with a primary aim to strengthen global capital, liquidity and risk assessment rules and so to ensure higher resiliency of a banking sector. We agree with Teplý et al. (2012) who state the Basel III regulation is not sufficient and will not prevent financial markets from future crises due to its expected calibration, delayed implementation and strong pressure from the bank lobbyists. We also discussed two main banking regulations being currently applied across the European Union: CRD IV and higher capital requirements set by the EBA (2010). As a consequence of 'bad deleveraging', the Eurozone banks are supposed to react on higher capital requirements primarily through asset contraction. We believe that this deleveraging, together with further regulatory rules under Basel III and the existence of zombie banks, will hinder rather than support economic recovery in the Eurozone in the short-term, as documented by slow economic growth of the Eurozone as of May 2014. 
Against this theoretical backdrop, we provided an empirical test of the hypothesis whether the market would appreciate positively higher capital requirements, lower risk taking and less risky balance sheets of banks under the Basel III proposal. Our analysis employs fixed effects and methodology on financial data on 172 banks listed on European stock exchanges during the 2005-2011 period. We found out that an increase in common equity ratio, Tier 1 ratio and Total capital ratio by one percentage point in the past leads to a negative change in market capitalization of banks by $13.3 \%, 3.7 \%$ and $4.5 \%$ respectively. As a result, we reject the hypothesis defined in the beginning of this work stating that higher capital requirements can be positively appreciated by the market. Consequently, based on our findings we conclude that the impact of the Basel III regulation on the value of bank shares will probably be perceived negatively by the market, which could be reflected in a drop in the market value of the shares of the observed banks.

\section{References}

Abreu, M., Mendes, V. (2001), "Commercial Bank Interest Margins and Profitability: Evidence from Some EU Countries." Paper presented at the Proceedings of the Pan-European Conference Jointly Organised by the IEFS-UK \& University of Macedonia Economic \& Social Sciences, Thessaloniki, Greece, May 17-20, 2001.

Acharya, V. A. et al. (2010), Regulating Wall Street: The Dodd-Frank Act and the New Architecture of Global Finance. New York: Wiley Finance.

Asquith, P., Mullins, D. W. (1986), "Equity Issues and Offering Dilution." Journal of Financial Economics. Vol.5, pp. 61-89.

Athanasoglou, P., Delis, M., Staikouras (2006), "Determinants of Bank Profitability in the South Eastern European Region.” Munich Personal RePEc Archive No. 10274.

Awdeh, A., El-Moussawi, C., Machrouh, F. (2011), "The Effect of Capital Requirements on Banking Risk", International Research Journal of Finance and Economics, No. 66, pp. 133-146.

Barajas, A., Chami, R., Cosimano, T., Hakura, D. (2010), "U.S. Bank Behavior in the Wake of the 2007-2009 Financial Crisis," IMF Working Paper, International Monetary Fund.

BCBS (2009), Guidelines for Computing Capital for Incremental Risk in the Trading Book. Bank for International Settlements.

BCBS (2010), Basel III: A Global Regulatory Framework for More Resilient Banks and Banking Systems. Bank for International Settlements.

BCBS (2011a), Basel III rules: Summarizing Table. Bank for International Settlements.

BCBS (2011b), Global Systemically Important Banks: Assessment Methodology and the Additional Loss Absorbency Requirement. Rules text, Bank for International Settlements.

Berger, A. N. (1995), "The Relationship between Capital and Earnings in Banking." Journal of Money, Credit and Banking, Vol. 27, No. 2, pp. 432-456.

Berrospide, J. M., Rochelle, E. M. (2010), "The Effects of Bank Capital on Lending: What Do We Know? And What Does It Mean?" Finance and Economics Discussion Series No. 44, Federal Reserve Board, Washington D.C.

BIS (2012). Consolidated Banking Statistics. Retrieved on February 20, 2012 from http://www.bis.org/ statistics/consstats.htm.

Burnham, K. P., G. C. White (2002), "Evaluation of Some Random Effects Methodology Applicable to Bird Ringing Data." Journal of Applied Statistics, Vol. 29, No. 1-4, pp. 245-264. 
Cosimano, T. F., Hakura, D. S. (2011), "Bank Behavior in Response to Basel III: A Cross-Country Analysis." IMF Working Paper 11/119, International Monetary Fund.

Černohorská, L., Teplý, P. Vrábel, M. (2012), "The VT Index as an Indicator of Market Liquidity Risk in Slovakia." Journal of Economics, Vol. 60, No. 3, pp. 223-238.

Demirguc-Kunt, A., Detragiache, E., Merrouche, O. (2010), "Bank Capital: Lessons from the Financial Crisis." IMF Working Paper 10/286, International Monetary Fund.

Dewatripont, M. J., Tirole, J. (1994), "A Theory of Debt and Equity: Diversity of Security and Manager-Shareholder Congruence." Quarterly Journal of Economics, Vol. 109, pp. 1027-1054.

Dvořák, P. (2005), Banking for Bankers and Clients. Prague: Linde, 2005. European Banking Authority. (2011), "The EBA Publishes Recommendation and Final Results of Bank Recapitalisation Plan as Part of Co-ordinated Measures to Restore Confidence in the Banking Sector." European Banking Authority.

Eigengreen, B. (2014), "Europe's Crisis Treadmill." Retrieved on June 10, 2014, from http://www.project-syndicate.org/commentary/barry-eichengreen-takes-issue-with-those-whoclaim -that-the-eurozone-crisis-is-over.

European Commission. (2014), "Banking union." Retrieved on June 10, 2014, from http://ec.europa. eu/internal_market/finances/banking-union/index_en.htm.

European Commission. (2011). CRD IV - Frequently Asked Questions. Retrieved on February 17, 2012, from http://europa.eu/rapid/pressReleasesAction. do?reference=MEMO/11/527\&type $=H T M L$.

Fitzmaurice, G. M., Laird, N. M., Ware, J. H. (2004), Applied Longitudinal Analysis. John Wiley \& Sons, Inc., p. 326-328.

Goodhart, C. et al. (1998), Financial Regulation: Why, How, and Where Now? New York: Routledge, 1998.

IMF (2012), "Global Financial Stability Report," October 2012, Retrieved on December 29, 2012, rom http://www.imf.org/External/Pubs/FT/GFSR/2012/02/index.htm

Klinger, T., Teplý, P. (2014), "Systemic risk of the global banking system - an agent-based network model approach." Prague Economic Papers, Vol. 23, No. 1, pp. 24-41.

Lall, R. (2010), "Reforming Global Banking Rules: Back to the Future?" DIIS Working Paper No. 16.

Mandel, M., Tomšík, V. (2011), "Regulace bankovního sektoru z pohledu ekonomické teorie." Politická ekonomie, 2011, Vol. 59, No. 1, pp. 58-81.

Matejašák, M., Černohorský, J., Teplý, P. (2009), "The Impact of Regulation of Banks in the US and the EU-15 Countries“, E a M: Ekonomie a Management, Vol. 3, pp. 58-69.

Masulis, R. W., Korwar, A. N. (1985), "Seasoned Equity Offerings: An Empirical Investigation." Journal of Financial Economics, Vol. 15, No. 1/2, pp. 91-118.

Mehran, H., Thakor, A. (2009), "Bank Capital and Value in the Cross Section." Federal Reserve Bank of New York Staff Reports, No. 390

McKinsey (2011), "Day of Reckoning? New Regulation and Its Impact on Capital Markets Businesses." McKinsey Working Paper on Risk, No. 29.

McKinsey (2012), "Day of Reckoning for European Retail Banking." McKinsey Working Paper on Risk, No. 36.

Musílek, P. (2011), "European System of Financial Supervision." Český finanční a účetní časopis. Vol. 6, No. 2, pp. 7-17.

Myers, S. C., Majluf, N. S. (1984), "Corporate Financing and Investment Decisions When Firms Have Information that Investors Do Not Have." Journal of Financial Economics, Vol. 13, No. 2, pp. 187-221.

Laird, N. M., Ware, J.H. (1982),"Random-Effects Models for Longitudinal Data," Biometrics, Vol. 4, No. 38, pp. 963-974. 
Ngo, P. T. (2008), "Capital-Risk Decisions and Profitability in Banking: Regulatory versus Economic Capital." Australian National University, School of Finance and Applied Statistics.

Oliver Wyman, Morgan Stanley (2012), "Wholesale \& Investment Banking Outlook Decision Time for Wholesale Banks."

Onaran, Y. (2011), Zombie Banks: How Broken Banks and Debtor Nations Are Crippling the Global Economy. New York: Bloomberg Press.

Open Europe (2011), "No Way Out? The Short Term Options for the Eurozone." October 2011.

Pasiouras, F., Kosmidoua, K. (2007), "Factors Influencing the Profitability of Domestic and Foreign Commercial Banks in the European Union." Research in International Business and Finance, Vol. 21, No. 2, pp. 222-237.

PwC (2011), "Including Updates on CRD IV, Changes to Highly Automated Trading Environments and Universal Access to Basic Bank Accounts." Retrieved on 17 February 2012, from http://www.pwc. $\mathrm{com} / \mathrm{gx} / \mathrm{en} /$ financial-services/issues/regulation/european-fs-regulation-update/updates/ august-01-2011.jhtml.

PwC (2012), "Banking Industry Reform - a New Equilibrium." Retrieved on 15 August 2012, from http://www.pwc.com/en_GX/gx/banking-capital-markets/publications/assets/pdf/pwc-bankingindustry-reform-pdf.pdf.

Reinhart, C. M.; Rogoff, K. S. (2009), This Time Is Different: Eight Centuries of Financial Folly. Princeton: Princeton University Press, 2009.

Rippel, M., Suchánková, L, Teplý, P. (2012), "The Role of Insurance in Operational Risk Mitigation a Case Study." Politická ekonomie, Vol. 60, No. 4, pp. 523-35.

Rippel, M., Teplý, P. (2011), "Operational Risk - Scenario Analysis." Prague Economic Papers, Vol. 20, No. 1, pp. 23-39.

Šútorová, B. (2012), "The Impact of Basel III on European Banks." Master thesis. Prague: Institute of Economic Studies, Faculty of Social Sciences, Charles University.

Revenda, Z. et al. (2012), Peněžní ekonomie a bankovnictví. $5^{\text {th }}$ edition. Prague: Management Press, 2012.

Stádník, B. (2013), "Market Price Forecasting and Profitability - How To Tame Random Walk?" Verslas: Teorija ir Praktika / Business: Theory and Practice, Vol. 14, No. 2, pp. 166-176.

Stádník, B. (2014), "The Riddle of Volatility Clusters." Verslas: Teorija ir Praktika / Business: Theory and Practice, Vol. 15, No. 2, pp. 160-170.

Stigler, G. J. (1971), "The Theory of Economic Regulation", Bell Journal of Economics and Management Science, Vol. 2, spring 1971, pp. 3-21.

Šinka, M., Teplý, P. (2011), "The (Non)Sense of Private Equity Regulation?" Scientific Papers of the University Pardubice, Vol. 2, pp. 155-166.

Šútorová, B., Teplý, P. (2013), "The impact of Basel III on lending rates of EU banks," Czech Journal of Finance, Vol. 63, No. 3, pp. 226-243.

Teplý, P. Diviš, K, Černohorská, L. (2007), "Implications of the New Basel Capital Accord for European Banks." E+M Journal, Vol. 1, pp. 59-65.

Teplý, P. et al. (2012), Economic Capital and Risk Management. Prague: Karolinum press, 2012.

Teplý, P. (2012), "The Application of Extreme Value Theory in Operational Risk Management." Journal of Economics, Vol. 60, No. 7, pp. 698-716.

Valkanov, E., Kleimeier, S. (2007), "The Role of Regulatory Capital in International Bank Mergers and Acquisitions." Research in International Business and Finance, Vol. 21, No.1, pp. 50-68.

Wehinger, G. (2012). "Bank Deleveraging, the Move from Bank to Market-based Financing, and SME Financing." OECD Journal: Financial Market Trends, Volume 2012/1. 


\section{Appendix}

\section{Tests for suitability of methodologies for panel data regression}

Test for differing group intercepts

$\mathrm{H}_{0}$ : Groups have a common intercept (FE suitable)

$\mathrm{H}_{1}$ : Groups do not have a common intercept (FE not suitable)

\begin{tabular}{|l|c|c|}
\hline Type of ratio used in the equation & F Statistics & p-value \\
\hline Common equity Ratio & $\begin{array}{c}1.51973 \\
\text { (d.f.: } 94,230)\end{array}$ & 0.00616776 \\
\hline Tier 1 Ratio & $\begin{array}{c}1.33713 \\
\text { (d.f.: 93, 220) }\end{array}$ & 0.0434173 \\
\hline Total Capital Ratio & $\begin{array}{c}1.50156 \\
\text { (d.f.: 93, 220) }\end{array}$ & 0.00772801 \\
\hline
\end{tabular}

\section{Hausman specification test}

$\mathrm{H}_{0}$ : GLS estimates are consistent (RE suitable)

$\mathrm{H}_{1}$ : GLS estimates are not consistent (RE not suitable)

\begin{tabular}{|l|c|c|}
\hline Type of ratio used in the equation & \multicolumn{1}{|c|}{$\boldsymbol{X}^{2}$} & p-value \\
\hline Common equity Ratio & 89.0096 (d.f.: 8) & $7.38693 \mathrm{e}-016$ \\
\hline Tier 1 Ratio & 58.8047 (d.f.: 8) & $7.99342 \mathrm{e}-010$ \\
\hline Total Capital Ratio & 77.7494 (d.f.: 8) & $1.38585 \mathrm{e}-013$ \\
\hline
\end{tabular}

The magnitudes of $p$-values indicate that the FE is preferred to the RE 